\title{
PENGARUH KUALITAS PRODUK, DESAIN PRODUK, DAN FITUR PRODUK TERHADAP KEPUTUSAN PEMBELIAN SMARTPHONE SAMSUNG (STUDI PADA MAHASISWA STIE LABUHANBATU)
}

\author{
Al-Ansori Afda'u Nasution', Abd. Rasyid Syamsuri \\ ${ }^{1}$ Alumni Sarjana Ekonomi STIE Labuhanbatu \\ ${ }^{2}$ Dosen STIE Labuhanbatu
}

\begin{abstract}
ABSTRAK
Penelitian ini bertujuan untuk mengetahui dan menganalisis pengaruh kualitas produk, desain produk, dan fitur produk terhadap keputusan pembelian smartphone Samsung pada Mahasiswa STIE Labuhanbatu. Teknik pengambilan sampel menggunakan metode purposive sampling, yaitu sampel yang dipilih dengan kriteria tertentu berjumlah 89 orang. Hasil uji hipotesis secara serempak (Uji F) variabel kualitas produk, desain produk, dan fitur produk berpengaruh secara positif dan signifikan terhadap keputusan pembelian. Pada uji hipotesis parsial (Uji t) variabel kualitas produk dan fitur produk berpengaruh positif dan signifikan terhadap keputusan pembelian. Sedangkan, variabel desain produk berpengaruh secara positif tetapi tidak signifikan terhadap keputusan pembelian. Hasil uji determinasi diperoleh nilai Adjusted $R$ Square $\left(R^{2}\right)$ sebesar 0,313. Artinya variabel keputusan pembelian dapat dijelaskan sebesar 31,3\% oleh variabel kualitas produk, desain produk, dan fitur produk, sementara sisanya $68,7 \%$ dijelaskan oleh variabel lain yang tidak dimasukkan dalam penelitian ini
\end{abstract}

Kata Kunci:KualitasProduk, DesainProduk, FiturProduk, KeputusanPembelian.

\section{Pendahuluan}

Persaingan yang ketat diantara produsen smartphone tidak hanya menempatkan konsumen sebagai pihak yang pasif, dalam hal ini hanya menerima dan menggunakan produk saja, tetapi konsumen bertindak sebagai pengambil keputusan untuk produk yang dipilihnya di tengah situasi banyaknya pilihan produk yang dapat dipilih,sehingga persaingan ini membuat produsen harus terus-menerus meningkatkan kualitas produknya serta melakukan inovasiinovasi dalam hal desain dan fitur produknya agar sesuai dengan apa yang menjadi kebutuhan dan selera konsumen saat ini.
Munculnya produsen-produsen baru membuat persaingan dalam harga tidak lagi menjadi fokus utama, para produsen berusahan menjangkau seluruh segmen konsumennya. Fenomena ini juga terlihat pada iklan dan promosi yang dilakukan oleh produsen smartphone itu sendiri, saat ini iklan yang dibuat fokus pada kemampuan produk smartphone tersebut bahkan menggambarkan secara detail tentang kualitas, desain dan fitur produk smartphone tersebut. Hal ini memberi gambaran bahwa ketiga aspek ini dipandang penting untuk menciptakan keunggulan dan merebut hati konsumen.

Sumber informasi mengenai suatu produk yang dapat membantu kita memberi penilaian terhadap produk 
tersebut. Keadaan ini membuat konsumen semakin cerdas dalam menentukan keputusan membelinya. Konsumen semakin memperhatikan kualitas produk yang akan dipilihnya. Khususnya terhadap produk smartphone, aspek kualitas menjadi sangat penting mengingat tingkat penggunaannya yang tinggi dan digunakan dalam jangka waktu yang cukup panjang. Tentunya konsumen akan memilih smartphone yang mampu memberikan kinerja yang baik dan dapat memenuhi kebutuhannya serta memiliki daya tahan yang dapat diandalkan.

Selain itu, konsumen juga memperhatikan desain dari smartphone itu sendiri. Bentuk dan warna menarik yang sesuai dengan selera konsumen serta desain yang mendukung fungsi produk itu sendiri akan menjadi nilai tambah bagi smartphone tersebut. Desain merupakan aspek yang paling mudah diamati oleh konsumen. Desain dapat memberikan gambaran awal mengenai produk tersebut sehingga penting bagi produsen untuk memperhatikan aspek ini.

Kebutuhan konsumen terhadap ponsel tidak hanya sekedar menjadi alat untuk berkomunikasi dengan mengirim pesan atau telepon saja tetapi juga menjadikannya sebagai sarana hiburan, perangkat yang membantu dalam pekerjaan, dan alat untuk memperoleh informasi. Dalam kaitannya dengan situasi tersebut, smartphone menyediakan fitur-fitur yang sangat lengkap yang dapat memenuhi kebutuhan konsumen saat ini. Media foto dan gambar yang semakin beragam, pemutar musik, sistem operasi (operating system) yang menarik, akses internet dan media sosial, serta berbagai fitur lainnya memungkinkan para penggunanya dengan cepat bertukar informasi dengan pengguna lain.
Salah satu pangsa pasar potensial dalam menggunakan smartphone Samsung adalah di kalangan mahasiswa. Hal ini disebabkan karena mahasiswa lebih peka terhadap perkembangan teknologi termasuk teknologi smartphone. Umumnya dikalangan mahasiswa smartphone digunakan untuk akses sosial media (seperti Facebook, Twitter, Instagram, Path, dan sebagainya), Browsing, dan juga banyak digunakan untuk transaksi belanja di online shop. Berbagai brand smartphone banyak digunakan oleh mahasiswa termasuk smartphone Samsung. Banyak faktor dan alasan pemilihan samrtphone Samsung di kalangan mahasiswa, misalnya kulitas produk, fitur, desain, varian produk, dan juga harga.

\section{Tinjuan Pustaka}

Kotler dan Armstrong (2008:272) menjelaskan bahwa manfaat dari produk dikomunikasikan melalui atribut produk yang terdiri atas kualitas produk, desain produk, dan fitur produk. Tjiptono (2001:103) menjelaskan bahwa atribut produk merupakan aspek yang penting dari sebuah produk karena menjadi dasar pertimbangan konsumen untuk membuat keputusan pembelian, artinya ketiga variabel tersebut mampu mempengaruhi konsumen dalam pengambilan keputusan pembelian (Y).

Kotler dan Keller (2009:10) menjelaskan bahwa dengan memperbaiki kualitas produk perusahaan dapat memperoleh pangsa pasar yang tinggi. Pangsa pasar yang tinggi dapat diperoleh bila konsumen memutuskan untuk membeli atau mengkonsumsi produk perusahaan tersebut.

Selain itu dalam Kotler dan Keller (2009:11) dijelaskan bahwa desain menawarkan cara potensial untuk 
mendiferensiasikan perusahaan dan memposisikan produknya, artinya jika perusahaan sudah mampu menciptakandiferensiasi dan keunggulan bersaing maka konsumen akan tertarik untuk membeli. Kotler dan Armstrong (2008:273) mengatakan bahwa fitur menjadi sarana konpetitif untuk mendiferensiasikan produk perusahaan dari pesaing. Fitur yang bernilai baik menjadi cara yang efektif untuk bersaing. Dengan adanya fitur yang menarik dan bermanfaat bagi konsumen, konsumen akan memilih produk tersebut.

\section{Metode Penelitian}

Populasi dan Sampel

Populasi dalam penelitian ini adalah Mahasiswa STIE Labuhanbatu Rantauprapat yang masih aktif kuliah. Berdasarkan data Biro STIE Labuhanbatu, jumlah mahasiswa STIE Labuhanbatu Rantauprapat Tahun Ajaran 2015/2016 seluruhnya berjumlah 805 orang.

Dalam penelitian ini yang menjadi sampel penelitian adalah mahasiswa STIE Labuhanbatu yang menggunakan smartphone Samsung. Penentuan jumlah sampel digunakan rumus Slovin yaitu :

$$
\begin{aligned}
& n=\frac{N}{\left(1+N e^{2}\right)} \\
& n=\frac{805}{\left(1+805(10 \%)^{2}\right)} \\
& n=88,95, \\
& \text { dengan demikian jumlah sampel } \\
& \text { dibulatkan menjadi } 89 \text { responden. }
\end{aligned}
$$

Dalam penelitian ini desain pengambilan sampel yang digunakan adalah nonprobability sampling. Sedangkan teknik yang digunakan adalah purposive sampling, dimana sampel diambil berdasarkan beberapa kriteria yang dibuat oleh peneliti. Pengambilan sampel ini didasarkan pada dua kriteria yaitu:

1. Responden merupakan mahasiswa STIE Labuhanbatu T.A 2015/2016.

2. Responden memiliki dan menggunakan smartphone Samsung.

\section{Jenis dan Sumber Data}

Data yang digunakan dalam penelitian ini adalah :

1. Data primer

Data primer adalah data yang diperoleh secara langsung dari sumber asli (tanpa perantara). Data primer yang ada dalam penelitian ini merupakan hasil penyebaran kuesioner pada sampel yang telah ditentukan.

2. Data sekunder

Data sekunder adalah data penelitian yang diperoleh secara tidak langsung dari sumbernya melalui dokumendokuemn atau catatan tertulis.

\section{Teknik Pengumpulan Data}

Teknik pengumpulan data dalam penelitian ini adalah :

1. Daftar Pernyataan (Kuesioner) Merupakan teknik pengumpulan data yang dilakukan dengan memberikan sejumlah daftar pernyataan yang tertulis kepada responden untuk dijawabnya.

2. Wawancara yaitu dengan melakukan tanya jawab atau wawancara secaralangsung dengan pihak-pihak yang terkait dengan objek penelitian untukmendapatkan informasi.

3. Studi Dokumentasi

Studi dokumentasi yaitu mengumpilkan data melalui buku, jurnal, majalah, internet yang menjadi bahan referensi pendukung bagi peneliti. 


\section{Metode Analisis Data}

Uji Asumsi Klasik

Sebelum data dianalisis, maka model regresi berganda harus memenuhi syarat uji asumsi klasik yang terdiri atas:

1) Uji Normalitas

Uji normalitas dilakukan untuk menguji apakah dalam model regresi, variabel bebas dan variabel terikat atau keduanya telah terdistribusi secara normal atau tidak. Model regresi yang baik adalah model yang memiliki distribusi normal atau mendekati normal. Normalitas dapat dideteksi dengan melihat penyebaran data (titik) dari sumbu diagonal dari grafik atau melihat histogram dari residualnya.

2) Uji Heteroskedastisitas

Uji model asumsi klasik yang kedua adalah uji heteroskedastisitas. Uji ini dilakukan untuk menguji apakah varians variabel dalam model tidak sama (konstan). Konsekuensi adanya heteroskedastisitas dalam model regresi adalah penaksir (estimator) yang diperoleh tidak efisien, baik dalam sampel kecil ataupun sampel besar, walaupun penaksir yang digunakan menggambarkan populasi (tidak bias) dan bertambahnya sampel yang digunakan akan mendekati nilai sebenarnya (konsisten) ini disebabkan oleh variansnya yang tidak minimum.

Model regresi yang baik adalah bila tidak terjadi heteroskedastisitas. Cara yang dapat dilakukan untuk mendeteksi heteroskedastisitas adalah melihat grafik scatterplot antara nilai prediksi (*ZPRED) dengan nilai residualnya (*ZRESID). *ZPRED dan *ZRESID merupakan nilai prediksi dan residual yang telah distandarisasi. Nilainya memang berubah, tetapi skalanya tidak,sehingga tetap mencerminkan data sesungguhnya
(Usman dan Sobari, 2013:78). Indikasi terjadinya heterosdekastisitas dapat dilihat bila terjadi pola sistematik tertentu pada plot seperti titik-titik yang membentuk pola yang teratur, namun bila tidak terdapat pola yang jelas serta titik-titik nya menyebar maka bisa diindikasikan model regresi bebas dari heterosdekastisitas.

3) Uji Multikoliniearitas

Uji model asumsi klasik selanjutnya adalah uji multikoliniearitas. Uji ini dilakukan untuk mengetahui apakah ada korelasi antara variabel independennya (Usman dan Sobari, 2013:75). Konsekuensi penting bagi model regresi yang mengandung multikolinieritas adalah kesalah standar estimasi akan cenderung meningkat dengan bertambahnya variabel independen, tingkat signifikansi untuk menolak hipotesis nol akan semakin besar, dan probabilitas menerima hipotesis yang salah juga akan semakin besar. Pengujian multikolniearitas dalam penelitian ini dilakukan dengan melihat nilai dari Variance Inflation Factor (VIF) dan nilai Tolerance-nya. Jika nilai VIF < 5 dan nilai Tolerancenya $>0,1$ maka tidak terjadi multikoliniearitas.

\section{Analisis Regresi Linear Berganda}

Analisis regresi linear berganda digunakan untuk menganalisis seberapa besar pengaruh dan hubungan antara variabel bebas dengan variabel terikat. Analisis regresi berganda digunakan karena jumlah variabel bebas yang akan diteliti berjumlah lebih dari satu variabel. Dalam penelitian ini peneliti menggunakan aplikasi SPSS 20 for Windows untuk menghitung model regresi berganda ini. Rumus matematisnya adalah : 
$\mathbf{Y}=\mathbf{a}+\mathbf{b}_{1} \mathbf{X}_{1}+\mathbf{b}_{2} \mathbf{X}_{2}+\mathbf{b}_{3} \mathbf{X}_{3}+e$

Dimana :

$\mathrm{Y} \quad=$ Keputusan Pembelian

$\mathrm{a} \quad=$ Konstanta

$\mathrm{b}_{1}-\mathrm{b}_{3}=$ Koefisien regresi

$\mathrm{X}_{1} \quad=$ Kualitas Produk

$\mathrm{X}_{2} \quad=$ Desain Produk

$\mathrm{X}_{3}=$ Fitur Produk

$e \quad=$ Standar error

\section{Uji Hipotesis}

1) Uji Parsial (Uji t)

Uji $t$ pada dasarnya menunjukkan seberapa jauh pengaruh satu variabel independen secara individual dalam menerangkan variasi variabel dependen (Kuncoro, 2009:238). Uji t dalam penelitian ini bertujuan untuk melihat secara parsial apakah variabel $\mathrm{X}$ yaitu kualitas produk $\left(\mathrm{X}_{1}\right)$, desain produk $\left(\mathrm{X}_{2}\right)$, dan fitur produk $\left(\mathrm{X}_{3}\right)$ berpengaruh signifikan terhadap keputusan pembelian (Y). Bentuk pengujiannya adalah :

- $\mathrm{H}_{0}: \mathrm{bi}=0$, artinya secara parsial tidak terdapat pengaruh yang signifikan antarakualitas produk $\left(\mathrm{X}_{1}\right)$ desain produk $\left(\mathrm{X}_{2}\right)$, dan fitur produk $\left(\mathrm{X}_{3}\right)$ terhadap keputusan pembelian $(\mathrm{Y})$.

- $\mathrm{H}_{\mathrm{a}}$ : bi $\neq 0$, artinya secara parsial terdapat pengaruh yang signifikan signifikan antarakualitas produk $\left(\mathrm{X}_{1}\right)$ desain produk $\left(\mathrm{X}_{2}\right)$, dan fitur produk $\left(\mathrm{X}_{3}\right)$ terhadap keputusan pembelian (Y).

Dalam melakukan uji parsial (uji t), peneliti menggunakan alat bantu aplikasi SPSS 20.0 for Windows.

Kriteria pengambilan keputusan, yaitu:

- $\mathrm{H}_{0}$ diterima apabila nilai $\mathrm{t}_{\text {hitung }}<\mathrm{t}_{\text {tabel }}$, dan Sig> 0,05.

- $\mathrm{H}_{\mathrm{a}}$ diterima apabila nilai $t_{\text {hitung }}>\mathrm{t}_{\text {tabel }}$, dan $\mathrm{Sig}<0,05$

2) Uji Simultan (Uji F)

Uji F secara mendasar menunjukkan apakah semua variabel bebas yang dimasukkan dalam model mempunyai pengaruh secara bersama-sama terhadap variabel dependen (Kuncoro, 2009:239). Uji Fdalam penelitian ini bertujuan untuk melihat apakah variabel $\mathrm{X}$ yaitu kualitas produk $\left(\mathrm{X}_{1}\right)$, desain produk $\left(\mathrm{X}_{2}\right)$, dan fitur produk $\left(\mathrm{X}_{3}\right)$ secara bersama (simultan) berpengaruh signifikan terhadap keputusan pembelian (Y). Bentuk pengujiannya adalah :

- $\mathrm{H}_{0}: \mathrm{b} 1=\mathrm{b} 2=0$, artinya secara bersama-sama (simultan) tidak terdapat pengaruh yang signifikan antarakualitas produk $\left(\mathrm{X}_{1}\right)$, desain produk $\left(\mathrm{X}_{2}\right)$, dan fitur produk $\left(\mathrm{X}_{3}\right)$ terhadap keputusan pembelian $(\mathrm{Y})$.

- Ha : b1 $\neq \mathrm{b} 2 \neq 0$, artinya secara bersama-sama (simultan) terdapatpengaruh yang signifikan antarakualitas produk $\left(\mathrm{X}_{1}\right)$, desain produk $\left(\mathrm{X}_{2}\right), \quad$ dan fitur produk $\left(\mathrm{X}_{3}\right)$ terhadap keputusan pembelian (Y).

Dalam melakukan uji parsial (uji F), peneliti menggunakan alat bantu aplikasi SPSS 20.0 for Windows.

Kriteria pengambilan keputusan yaitu :

- $\mathrm{H}_{0}$ diterima apabila nilai $\mathrm{F}_{\text {hitung }}<$ $\mathrm{F}_{\text {tabel, }}$ dan nilai Sig $>0,05$.

- $\mathrm{H}_{\mathrm{a}}$ diterima apabila nilai $\mathrm{F}_{\text {hitung }}>$

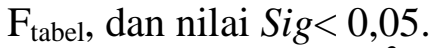

3) Koefisien Determinasi $\left(R^{2}\right)$

Koefisien determinasi $\left(R^{2}\right)$ pada dasarnya mengukur seberapa jauh kemampuan suatu model dalam menerangkan variase variabel terikat. Nilai koefisien determinasi adalah di antara nol dan satu. Nilai $R^{2}$ yang kecil memberi arti bahwa kemampuan variabel bebas dalam menjelaskan variasi variabel terikat amat terbatas. Sedangkan bila nilai $R^{2}$ besar (mendekati 1) berarti variabel bebas 
memberikan hampir semua informasi yang dibutuhkan untuk memprediksi variasi variabel dependen.

\section{Hasil Dan Pembahasan}

\section{Hasil Uji Asumsi Klasik}

1) Uji Normalitas

Uji normalitas untuk melihat apakah nilai residual telah terdistribusi normal. Uji normalitas dapat dilakukan dengan 2 cara yaitu:

a) Analisis Grafik

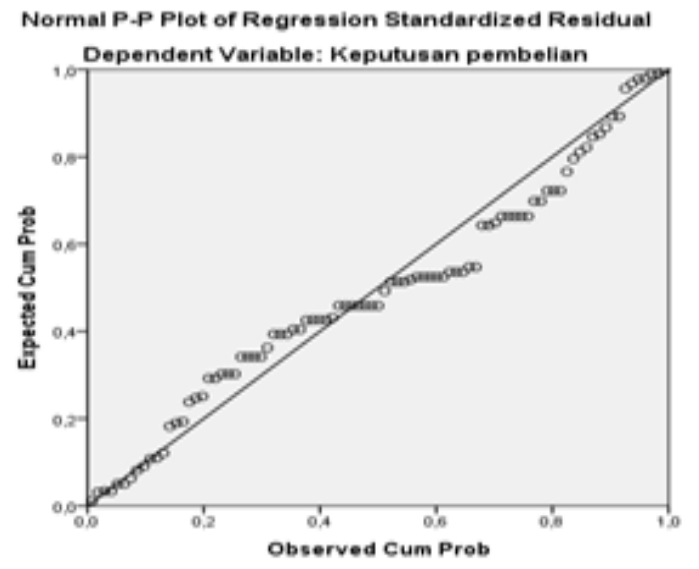

Gambar1 Grafik P-Plot Uji Normalitas

Pada gambar 1 grafik P-Plot menunjukkan bahwa data berada di sekitar garis diagonal dan membentuk pola yang mengikuti garis diagonal. Hal ini menunjukkan bahwa data memenuhi asumsi normalitas.

b) UjiKolmogorov-Smirnov

Uji normalitas juga bisa dilakukan dengan analisis Kolmogorov-Smirnov. Kriteria keputusan yang diambil adalah :

- Jika nilai Asymp. Sig. (2-tailed)> 0,05 maka tidak mengalami gangguan distribusi normal.

- Jika nilai Asymp. Sig. (2-tailed)< 0,05 maka mengalami gangguan distribusi normal.
Tabel 1 Uji Kolmogorov-Smirnov

One-Sample Kolmogorov-Smimov Test

\begin{tabular}{|c|c|c|}
\hline & & $\begin{array}{c}\text { Unsta ndardized } \\
\text { Residual }\end{array}$ \\
\hline $\begin{array}{l}\text { N } \\
\text { Normal Parameters } \\
\text { Most Extreme Differences } \\
\text { Kolmogorov-Smirnov Z } \\
\text { Asymp. Sig. (2-tailed) }\end{array}$ & $\begin{array}{l}\text { Mean } \\
\text { Sul. Deviation } \\
\text { Absolute } \\
\text { Positive } \\
\text { Negative }\end{array}$ & $\begin{array}{r}89 \\
\text { OE-7 } \\
, 61689150 \\
, 126 \\
, 126 \\
-, 087 \\
1,191 \\
, 117 \\
\end{array}$ \\
\hline
\end{tabular}

Tabel 1 menunjukkan hasil analisis statistik Kolmogorov-Smirnov. Pada tabel tersebut dapat dilihat nilai Asymp.sig (2-tailed) adalah 0,117, dimana nilainya lebih besar daripada 0,05 . Hal ini menunjukkan bahwa model regresi telah memenuhi asumsi normalitas.

2) Uji Multikolinearitas

Uji multikoliniearitas bertujuan untuk menguji apakah terjadi korelasi yang tinggi diantara variabel bebas. Model regresi yang baik adalah model yang tidak mengalami multikoliniearitas. Uji ini dilakukan dengan melihat nilai Tolerance dan Variance Inflation Factor (VIF). Jika nilai Tolerance $>0,1$ dan VIF $<5$ maka model memenuhi asumsi multikoliniearitas. Nilai Tolerance dan VIF dapat dilihat pada Tabel 2.

Tabel 2 Uji Multikolinearitas

\begin{tabular}{|c|c|c|c|c|c|c|c|}
\hline \multirow[t]{2}{*}{ Nodel } & \multicolumn{2}{|c|}{$\begin{array}{l}\text { Unstandardized } \\
\text { Coefficents }\end{array}$} & \multirow{2}{*}{$\begin{array}{c}\begin{array}{c}\text { Standardized } \\
\text { Coeficients }\end{array} \\
\text { Beta }\end{array}$} & \multirow[t]{2}{*}{$t$} & \multirow[t]{2}{*}{ Sig. } & \multicolumn{2}{|c|}{ Collinearity Statsics } \\
\hline & $\begin{array}{ll}B \\
\end{array}$ & St, Error & & & & Tolerance & $V \mid F$ \\
\hline (Constant) & 7,911 & 1,447 & & 5,487 &, 000 & & \\
\hline Kualitasproduk & .228 &, 084 & 344 & 3,658 &, 001 &, 838 & 1,198 \\
\hline Dessinproduk &, 104 &, 070 & ,134 & 1,500 & ,137 &, 985 & 1,015 \\
\hline Fiturproduk & 191 &, 069 & 313 & 3,249 &, 002 &, 842 & 1,188 \\
\hline
\end{tabular}

Pada Tabel 2 menunjukkan nilai Tolerance $>0,1$ dan nilai VIF $<5$ yang artinya tidak terjadi masalah multikoliniearitas pada model regresi. 
3) Uji Heteroskedostisitas

Uji ini dilakukan untuk menguji apakah varians variabel dalam model tidak sama (konstan). Uji ini dapat dilakukan dengan melihat grafik scatterplot.

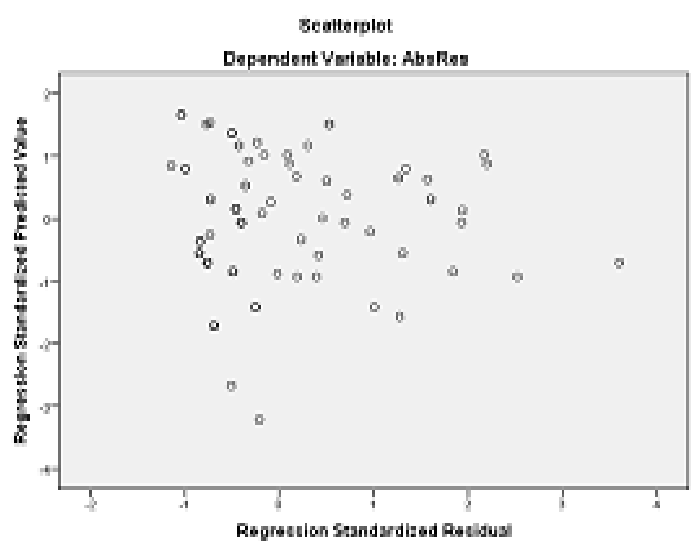

Gambar2. Scatterplot

Gambar 2 menunjukkan bahwa pola titik pada scatterplot menyebar di atas titik 0 dan tidak membentuk pola tertentu. Hal ini mengindikasikan bahwa model regresi tidak mengalami masalah heteroskedastisitas. Uji lain yang dapat dilakukan untuk melihat masalah heteroskedastisitas adalah Uji Glejser. Uji Glejser mengusulkan untuk meregresi nilai absolute residual terhadap variabel independen dengan persamaan regresi. Uji Glejser dilakukan dengan melihat nilai signifikansi variabel. Jika nilai signifikansi variabel > 0,05 maka tidak terdapat masalah heteroskedastisitas.

Tabel 3 Uji Glejser Coefficients"

\begin{tabular}{|c|c|c|c|c|c|}
\hline \multirow[t]{2}{*}{ Model } & \multicolumn{2}{|c|}{$\begin{array}{l}\text { Unstandarózed } \\
\text { Coeffcients }\end{array}$} & \multirow{2}{*}{$\begin{array}{c}\text { Standardized } \\
\text { Coeficients }\end{array}$} & \multirow[t]{2}{*}{$t$} & \multirow[t]{2}{*}{ Sig. } \\
\hline & $B$ & St. Error & & & \\
\hline (Constant) &, 194 & 989 & & 197 & 845 \\
\hline 1. Kualitasproduk &,- 038 &, 043 &,- 098 & .821 & .414 \\
\hline Destinproduk & -011 &, 048 & .024 & $\cdot 228$ & .822 \\
\hline Fiturproduk &, 062 &, 040 &, 182 & 1,560 &, 123 \\
\hline
\end{tabular}

Pada tabel 3 dapat dilihat bahwa nilai Signifikansi dari kualitas produk $(0,441)$, desain produk $(0,822)$, dan fitur produk $(0,123)>0,05$. Hal ini menunjukkan bahwa model regresi tidak mengalami masalah heteroskedastisitas.

\section{Hasil Analisis Regresi Linear Berganda}

Analisis regresi linear berganda ditujukan untuk mengetahui pengaruh atauhubungan variabel bebas $\left(\mathrm{X}_{1}, \mathrm{X}_{2}\right.$, dan $\mathrm{X}_{3}$ ) yaitu variabel kualitas produk, desain produk, dan fitur produkterhadap variabel terikat (Y) berupa keputusan pembelian. Maka untuk memperoleh hasil yang lebih akurat, peneliti menggunakanbantuan program software SPSS (Statistik Product and Service Solution) versi 20.0 dari tabel coefficient maka dihasilkan output sebagai berikut:

\section{Tabel 4 Analisis Regresi Berganda}

\begin{tabular}{|c|c|c|c|c|c|}
\hline & \multicolumn{4}{|c|}{ Coefficients" } & \multirow{3}{*}{ Sig. } \\
\hline \multirow[t]{2}{*}{ Modele| } & \multicolumn{2}{|c|}{ Unstandardized Coeficients } & $\begin{array}{l}\text { Standarized } \\
\text { Coeficents }\end{array}$ & $t$ & \\
\hline & $B$ & Std. Error & Beta & & \\
\hline (Constant) & 7,911 & 1,447 & & 5,487 & .000 \\
\hline Kualitbsproduk & .228 & .084 & 344 & 3,568 & .001 \\
\hline Desainproduk & , 104 & , 770 &, 134 & 1,500 & ,137 \\
\hline Fiturpooduk & ,191 & 059 & 313 & 3,249 & .002 \\
\hline
\end{tabular}

Berdasarkan Tabel 4 pada kolom Unstandardized Coefficients bagian B diperoleh nilai sebagai berikut :

1) Konstanta (a) $=7,911$. Ini mempunyai arti bahwa jika kualitas produk, desain produk, dan fitur produk dianggap konstan maka keputusan pembeli konsumen (Y) sebesar 7,911.

2) Koefisien $X_{1}\left(b_{1}\right)=0,226$. Koefisien regresi variabel kualitas produk sebesar 0,226 artinya variabel kualitas produk mempunyai pengaruh positif terhadap keputusan pembelian dan tiap kenaikan satu tingkat variabel kualitas produk dengan mengabaikan variabel 
lainnya akan menyebabkan kenaikan variabel keputusan pembelian sebesar 0,226 .

3) Koefisien $X_{2}\left(b_{2}\right)=0,104$. Koefisien regresi variabel desain produk sebesar 0,104 artinya variabel desai produk mempunyai pengaruh positif terhadap keputusan pembelian dan tiap kenaikan satu tingkat variabel desain produk dengan mengabaikan variabel lainnya akan menyebabkan kenaikan variabel keputusan pembelian sebesar 0,104 .

4) Koefisien $X_{3}\left(b_{3}\right)=0,191$.Koefisien regresi variabel fitur produk sebesar 0,191 artinya variabel fitur produk mempunyai pengaruh positif terhadap keputusan pembelian dan tiap kenaikan satu tingkat variabel fitur produk dengan mengabaikan variabel lainnya akan menyebabkan kenaikan variabel keputusan pembelian sebesar 0,191 .

Dengan demikian, persamaan regresi yang dihasilkan adalah sebagai berikut :

$Y=7,911+0,226 X_{1}+0,104 X_{2}+$ $\mathbf{0 , 1 9 1 X}_{3}+e$

\section{Hasil Pengujian Hipotesis}

Hipotesis pada penelitian ini diuji dengan menggunakan uji signifikansi parsial (Uji t), uji signifikansi simultan (Uji F), dan koefisien determinasi $\left(R^{2}\right)$.

1) Hasil Uji Signifikansi Parsial (Uji t)

Uji $t$ digunakan untuk mengetahui sejauhmana pengaruh variabel bebas $\left(\mathrm{X}_{1}, \mathrm{X}_{2}\right.$, dan $\left.\mathrm{X}_{3}\right)$ secara parsial terhadap variabel terikat (Y). Uji $\mathrm{t}$ dilakukan dengan cara membandingkan nilai $\mathrm{t}_{\text {hitung }}$ dengan $t_{\text {tabel. }}$. Nilai $t_{\text {tabel }}$ yang digunakan adalah nilai $\mathrm{t}$ pada derajat kebebasan $(\mathrm{df})=\mathrm{n}$ $\mathrm{k}=89-4=85$ dengan $\alpha=0,05$ yaitu $1,66298=1,663$.
Kriteria pengambilan keputusan adalah:

- $\mathrm{H}_{0}$ diterima jika $\mathrm{t}_{\text {hitung }}<\mathrm{t}_{\text {tabel }}$ pada $\alpha=$ $5 \%$.

- Ha diterima jika $\mathrm{t}_{\text {hitung }}>\mathrm{t}_{\text {tabel }}$ pada $\alpha=$ $5 \%$.

Tabel 5 Hasil Uji Parsial (Uji t)

\begin{tabular}{|c|c|c|c|c|c|c|}
\hline \multirow{2}{*}{\multicolumn{2}{|c|}{ Model }} & \multicolumn{2}{|c|}{ Unstandardized Coeficients } & \multirow{2}{*}{$\begin{array}{c}\begin{array}{l}\text { Standardized } \\
\text { Coefidents }\end{array} \\
\text { Beta }\end{array}$} & \multirow[t]{2}{*}{$t$} & \multirow[t]{2}{*}{ Sig. } \\
\hline & & $B$ & Std. Error & & & \\
\hline \multirow{4}{*}{1} & (Constant) & 7,911 & 1,447 & & 5,487 &, 000 \\
\hline & Kualitasproduk & 228 &, 084 &, 344 & 3,568 &, 001 \\
\hline & Dessinproduk & 104 &, 070 &, 134 & 1,500 &, 137 \\
\hline & Fiturproduk & 191 &, 059 &, 313 & 3,249 &, 002 \\
\hline
\end{tabular}

Berdasarkan data pada Tabel 5, maka dapat dijelaskan sebagai berikut:

1. Nilai $t_{\text {hitung }}$ variabel kualitas produk adalah 3,556 dan nilai $t_{\text {tabel }} 1,663$, maka $t_{\text {hitung }}>t_{\text {tabel }}(3,556>1,663)$ dengan taraf signifikansi $(0,001<$ $0,005)$ sehingga dapat dikatakan bahwa variabel kualitas produk $\left(\mathrm{X}_{1}\right)$ secara parsial berpengaruh positif dan signifikanterhadap keputusan pembeliansmartphone Samsung pada mahasiswa STIE Labuhanbatu. Dengan demikian hipotesis dapat diterima.

2. Nilai $t_{\text {hitung }}$ variabel desain produk adalah 1,500 dan nilai $t_{\text {tabel }} 1,663$, maka $\mathrm{t}_{\text {hitung }}<\mathrm{t}_{\text {tabel }}(1,500<1,663)$ dengan taraf signifikansi $(0,137>$ $0,005)$ sehingga dapat dikatakan bahwa variabel desain produk $\left(\mathrm{X}_{2}\right)$ secara parsial berpengaruh positif tetapitidak signifikanterhadap keputusan pembeliansmartphone Samsung pada mahasiswa STIE Labuhanbatu. Dengan demikian hipotesis ditolak.

3. Nilai $t_{\text {hitung }}$ variabel fitur produk adalah 3,249 dan nilai $t_{\text {tabel }} 1,663$, maka $t_{\text {hitung }}>t_{\text {tabel }}(3,249>1,663)$ dengan taraf signifikansi $(0,002<0,005)$ sehingga dapat dikatakan bahwa 
variabel fitur produk $\left(\mathrm{X}_{3}\right)$ secara parsial berpengaruh positif dan signifikanterhadap keputusan pembeliansmartphone Samsung pada mahasiswa STIE Labuhanbatu. Dengan demikian hipotesis dapat diterima.

2) Hasil Uji Signifikansi Simultan (Uji F) Uji $F$ digunakan untuk mengetahui apakah semua variabel bebas $\left(\mathrm{X}_{1}, \mathrm{X}_{2}\right.$, dan $\mathrm{X}_{3}$ ) yang dimasukkan dalammodel mempunyai pengaruh secara bersamasama terhadap variabel terikat (Y).

Kriteria pengambilan keputusan adalah:

- $\mathrm{H}_{0}$ diterima jika $\mathrm{F}_{\text {hitung }}<\mathrm{F}_{\text {tabel }}$ pada $\alpha$ $=5 \%$.

- Ha diterima jika $F_{\text {hitung }}>F_{\text {tabel }}$ pada $\alpha$ $=5 \%$.

Nilai $F_{\text {hitung }}$ diperoleh dari hasil SPSS, dan nilai $F_{\text {tabelyang digunakan adalah }}$ nilai $F$ dengan derajat kebebasan (df) pada $\mathrm{df}_{1}=4-1=3$, dan $\mathrm{df}_{2}=89-4=$ $85, \alpha=0,05$ yaitu 2,71 .

\section{Tabel 6 Hasil Uji Simultan (Uji F)}

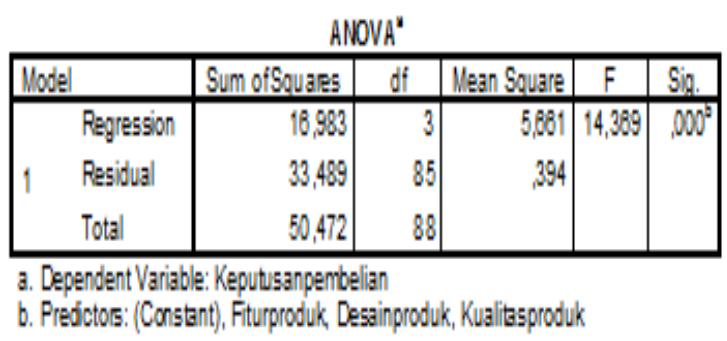

Berdasarkan hasil pengelolaan data yang ditunjukkan pada tabel 6 dapat dilihat bahwa nilai $F_{\text {hitung }}$ adalah sebesar 14,369 dan nilai signifikan adalah 0,000. Pada tingkat derajat kepercayaan $95 \%(\alpha=5 \%) \mathrm{F}_{\text {tabel }}$ adalah sebesar 2,71. Maka berdasarkan tabel 4.11 nilai $F_{\text {hitung }}(14,369)>F_{\text {tabel }}(2,71)$ dan nilai signifikan $0,000<0,05$. Artinya bahwa variabel kualitas produk $\left(\mathrm{X}_{1}\right)$, desain produk $\left(\mathrm{X}_{2}\right)$, dan fitur produk $\left(\mathrm{X}_{3}\right)$ secara serempak atau simultan berpengaruh positif dan signifikan terhadap keputusan pembelian smartphone Samsung pada mahasiswa STIE Labuhanbatu (Y). Dengan demikian hipotesis dapat diterima.

3) Koefisien Determinasi $\left(R^{2}\right)$

Pengujian koefisien determinasi $\left(R^{2}\right)$ dimaksudkan untuk melihat seberapa besar variabel keputusan pembelian smartphone Samsung pada mahasiswa STIE Labuhanbatu dapat dijelaskan oleh ketiga variabel bebasnya yaitu, variabel kualitas produk, desain produk, dan fitur produk. Tabel koefisien determinasi dapat dilihat pada tabel 7 .

Tabel 7 Koefisien Determinasi Model Summary

\begin{tabular}{|l|r|r|r|c|}
\hline Model & $R$ & R Square & $\begin{array}{c}\text { Adjusted } R \\
\text { Square }\end{array}$ & $\begin{array}{c}\text { St. Error of the } \\
\text { Estimate }\end{array}$ \\
\hline 1 &, $580^{2}$ & 336 &, 313 &, 62788 \\
\hline
\end{tabular}

Pada tabel 7 dapat dilihat nilai Adjusted $R$ Square sebesar 0,313. Hal ini menunjukkan bahwa variabel keputusan pembelian dapat dijelaskan oleh variabel kualitas produk, desain produk, dan fitur produk sebesar $31,3 \%$ dan sisanya sebesar $68,7 \%$ dijelaskan variabel lain yang tidak diikutsertakan dalam penelitian ini.

\section{Kesimpulan Dan Saran \\ Kesimpulan}

1. Secara serempak (bersama-sama) kualitas produk, desain produk, dan fitur produk berpengaruh positif dan signifikan terhadap keputusan pembelian smartphone Samsung pada mahasiswa STIE Labuhanbatu.

2. Secara parsial kualitas produk berpengaruh positif dan signifikan terhadap keputusan pembelian 
smartphone Samsung pada mahasiswa STIE Labuhanbatu.

3. Secara parsial desain produk berpengaruh positif tetapi tidak signifikan terhadap keputusan pembelian smartphone Samsung pada mahasiswa STIE Labuhanbatu.

4. Secara parsial fitur produk berpengaruh positif dan signifikan terhadap keputusan pembelian smartphone Samsung pada mahasiswa STIE Labuhanbatu.

5. Berdasarkan hasil uji deteminasi diperoleh nilai Adjusted $R$ Square sebesar 0,313, berarti 31,3\% variabel keputusan pembelian dapat dijelaskan oleh variabel kualitas produk, desain produk, dan fitur produk. Sedangkan sisanya $68,7 \%$ dapat dijelaskan oleh variabel lain yang tidak dimasukkan dalam penelitian ini.

\section{Saran}

1. Hasil penelitian menunjukkan bahwa variabel kualitas produk, desain produk, dan fitur produk memiliki pengaruh positif terhadap keputusan pembelian smartphone Samsung. Samsung harus bisa lebih lagi memberi perhatian dan lebih meningkatkan nilai produknya melalui ketiga aspek ini, karena ketiga variabel ini memiliki potensi yang besar untuk dapat menciptakan keunggulan bersaing.

2. Berdasarkan hasil penelitian, kualitas produk menjadi variabel yang paling dominan mempengaruhi keputusan pembelian smartphone Samsung. Artinya Samsung harus bisa menjaga dan meningkatkan keunggulan produknya dan terus berinovasi untuk menciptakan produk baru yang dapat memenuhi kebutuhan konsumen karena ke depan kebutuhan konsumen terhadap kualitas yang memudahkan aktivitas mereka akan semakin tinggi. Sedangkan untuk desain produk, Samsung dapat memperbaiki aspek tersebut dari segi tampilan produknya sehingga variabel tersebut dapat menjadi faktor penting yang mempengaruhi keputusan pembelian smartphone Samsung.

3. Penelitian ini hanya terbatas pada tiga variabel bebas yang diukur pengaruhnya terhadap keputusan pembelian. Bagi peneliti selanjutnya, sebaiknya penelitian dilakukan dengan menambahkan variabel lain misalnya dengan memasukkan variabel atribut produk lain seperti merek, jaminan/garansi, dan layanan pelengkap atau dapat juga mengembangkan indikator-indikator dari variabel yang digunakan dalam penelitian ini, sehingga dapat lebih memperkaya pengetahuan dan penelitian tentang keputusan pembelian smartphone.

\section{DAFTAR PUSTAKA}

Alana, Aditya Yesika, Wahyu Hidayat dan Handoyo Djoko W. 2012. "Pengaruh Citra Merek, Desain, dan Fitur Produk Terhadap Keputusan Pembelian Handphone Nokia (Studi Kasus pada Mahasiswa Universitas Diponegoro)". Universitas Diponegoro, Semarang.

Bruandari, Siti Fauzi. 2012. "Analisis Pengaruh Atribut Produk Terhadap Keputusan Pembelian Ponsel Merek Blackberry (Studi Kasus Mahasiswa Universitas Sebelas Maret Surakarta Tahun Ajaran 2011/2012)”. Surakarta: Universitas Sebelas Maret.

Ghozali, Imam. 2007. Aplikasi Analisis Multivariate dengan Program 
SPSS. Semarang : Badan Penerbit Universitas Diponegoro.

Gitosudarmo, Indriyo, H. 2008. Manajemen Pemasaran, Edisi Kedua. Yogyakarta : BPFE Yogyakarta.

Griffin, Ricky. W dan Ronald J. Ebert. 2008. Bisnis, Edisi Keenam. Jakarta : Indeks.

Handayani, Widya, 2013. "Pengaruh Atribut Produk Terhadap Keputusan Pembelian Handphone Samsung Galaxy Series”. Jakarta : Fakultas Ekonomi Universitas Gunadarma.

Kartajaya, Hermawandan Muhammad Syakir Sula. 2008. Syariah Marketing. Bandung :Mizan.

Kotler, Philip dan Gary Armstrong. 2008. Prinsip-Prinsip Pemasaran (Edisi 12).Jakarta :Erlangga.

Kotler, Philip dan Kevin Lane Keller, 2009. Manajemen Pemasaran (Edisi 13).Jakarta :Erlangga.

Kuncoro, Mudrajad. 2009. Metode Riset untuk Bisnis \& Ekonomi (Edisi 3). Jakarta:Erlangga.

Schiffman, Leon. G dan Leslie Lazar Kanuk, 2010. Perilaku Konsumen. Edisi Ketujuh. Jakarta :Indeks.

Soewito, Yudhi, 2013. "Kualitas Produk, Merek, dan Desain Pengaruhnya Terhadap Keputusan Pembelian Sepeda Motor Yamaha Mio". Jurnal EMBA, Universitas Sam Ratulangi, Manado, Vol.1 No.3, hal 218-229.

Sugiyono. 2012. Metode Penelitian Bisnis. Bandung :Alfabeta.

Suryani, Tati, 2013. Perilaku Konsumen di Era Internet dan Implikasinya pada Strategi Pemasaran. Yogyakarta :Graha Ilmu.
Sutisna, 2008. Perilaku Konsumen \& Komunikasi Pemasaran. Bandung : PT Remaja Rosdakarya.

Techno.id. 2015.“Penjualan Smartphone Samsung Menurun Dibanding Tahun Lalu”.

http://www.techno.id/tech-news, Diakses 18 Nopembember 2015.

Techinasia. 2015. "W\&S Group :Samsung Merek Smartphone Terpopuler di Indonesia”.

https://id.techinasia.com/pasarponsel-indonesia/. Diakses 18Nopember 2015.

Tjiptono, Fandy. 2005. Pemasaran Jasa. Edisi I. Malang : Bayumedia Pubishing.

Usman, Hardiusdan Nurdin Sobari. 2013. Aplikasi Teknik Multivariate untuk Riset Pemasaran. Jakarta : PT. Raja Grafindo Persada. 